\title{
COMPARISON OF THE SOMATIC STATE AND THE LEVEL OF MOTOR PERFORMANCE OF BOYS BETWEEN THE AGES OF SEVEN AND FIFTEEN IN THE OLOMOUC REGION (CZECH REPUBLIC) AND IN OPOLE (POLAND)
}

\author{
Miroslav Kopecký $^{1, *}$, Cezary Kusńierz ${ }^{2}$, Kateřina Kikalováa ${ }^{\text {, Jiří Charamza }}{ }^{1}$
}

\author{
${ }^{I}$ Faculty of Health Sciences, Palacký University, Olomouc, Czech Republic \\ ${ }^{2}$ Faculty of Physical Education and Physiotherapy, Opole University of Technology, Opole, Poland \\ ${ }^{3}$ Faculty of Education, Palacký University, Olomouc, Czech Republic
}

Submitted in April, 2013

\begin{abstract}
BACKGROUND: Recent years have seen a decrease in habitual movement activity in children and youth, which is being replaced by the predominance of a sedentary lifestyle. A reflection of these negative trends is also seen in the decrease in motor performance.

OBJECTIVE: The aim of this research is to analyze the level of the motor skills of contemporary 7 to 15 year olds in Olomouc and in Opole and to compare the physical parameters of Olomouc and Opole boys with the 6th NationWide Anthropological Survey of Children and Adolescents 2001 Czech Republic (the 6th CAV 2001).

METHODS: The research was carried out in both the Olomouc (695 boys) and Opole (313 boys) regions. For the diagnostics of the level of the motor performance of the boys, standardized motoric tests were used: the standing long jump with legs together, one-minute sit-ups, the $4 \times 10$ meter shuttle run, and throwing a medicine ball using both hands, as well as the testing battery UNIFITTEST (6-60). For the statistical evaluation of the results, Student's $t$-test, $Z$-scores and the non-parametric $\chi^{2}$-test were used.

RESULTS: The results have shown that, in height and weight, both boys from Olomouc and from Opole are in accordance with parameters, which correspond also to the reference data of the 6th CAV 2001. An identical performance level was reached by both sets of boys in the $4 \times 10 \mathrm{~m}$ shuttle run and in the standing long jump with legs together. In throwing the medicine ball with both hands, the Olomouc boys scored lower than the boys from Opole. During the period of their earlier school years, Olomouc boys scored higher in the one-minute sit-up test. The evaluation of individual motoric performance of boys in accordance with the testing battery UNIFITTEST (6-60) showed overall that $39 \%$ of the Olomouc boys and $42 \%$ of the Opole boys had less than average or even below average motoric performance levels. A comparison of the tested results of contemporary Olomouc and Opole boys with referential data for the Olomouc boys dating to 2001 and 2002 indicated a decrease in the speed, endurance and strength of their abdominal musculature and the dynamic-explosive capability of their upper and lower extremities.

CONCLUSIONS: The decrease in the motoric performance level of Olomouc and Opole boys probably reflects a decrease in habitual movement activity and the prevalence of a sedentary lifestyle.
\end{abstract}

Keywords: Boys 7 to 15 years of age, somatic state, motor skills, motoric tests, international comparison.

\section{INTRODUCTION}

Attention is being paid to the monitoring of somatic development, physical fitness and the level of movement activity among children and youth not only in the Czech Republic (Bunc, 2008; Frömel, Novosad, \& Svozil, 1999; Kopecký, 2006a; Moravec et al., 1990; Sigmund \& Sigmundová, 2011), but also in Poland

\footnotetext{
* Address for correspondence: Miroslav Kopecký, Department of Specialised Subjects and Practical Skills, Faculty of Health Sciences, Palacký University, tř. Svobody 8, 77111 Olomouc, Czech Republic. E-mail: miroslav.kopecky@upol.cz
}

(Asienkiewicz, 2007; Jopkiewcicz, Przychodni, Jopkiewizc, \& Krzystanek, 2011; Przeweda \& Dobosz, 2005). The physical development of children and youth is influenced by a number of factors, among the most important of which are heredity and various influences of both the internal and external surroundings, including physical activity, physical education and sport (Malina, Bouchard, \& Bar-Or, 2004).

Physical development and physical fitness are indicators of the state of health of a child and criteria for the judgement of normal growth and the forming of the organism at an appropriate age and is also a sensitive indicator of the levels of social and hygienic conditions 
of the population. The diagnostics of motoric performance with the help of standardized motoric tests reflect not only the current state of the physical fitness of the present population, but, at the same time, may provide us with important information about changes in the area of physical activity under the influence of socio-economic factors.

Anthropologists in this last century have been monitoring a clearly to be seen process of growth and development increasing in speed. The tempo of postnatal growth, reaching maturity as well as the adult values reached have changed in a very basic way (Bodzsár \& Susanne, 1998). In all countries with a higher socioeconomic level the physical height and weight of adults has increased and the speed of growth and development of children and yourth has increased (Bláha, Susanne, \& Rebato, 2007; Lobstein, Baur, \& Uauy, 2004; Lobstein \& Frelut, 2003; Ulijaszek, Johnston, \& Preece, 1998; Vignerová et al., 2005). On the basis of the analysis of the results of anthropometric research projects in the United States of America, Europe and Japan it is possible to state that, in developed countries, the secular trend in physical height is slowing to a halt, but in the case of physical weight it continues to increase. As a result, there is an increased occurrence of overweight and obesity in children of all age categories as well as in the adult population (Malina et al., 2004).

Anthropological studies of static parameters have shown a positive secular trend. In the case of the secular trend of motor skills this positive trend cannot be clearly established. Research projects concerned with the problematics of motor skills show, to the contrary, stagnation or a descending tendency of the secular trend in motor skills in the current population of children and youth in Germany (Hirtz, 2007), Poland (Asienkiewicz, 2007; Jopkiewicz et al., 2011; Przeweda \& Dobosz, 2005), the Czech Republic (Kopecký, 2006a, 2006b; Moravec et al., 1990) and in Slovakia (Jančoková, Kremnický, Misárošová, Mišurová, \& Kompán, 2002).

This trend to stagnation or to the reduction of motor skills can also be observed in the United States of America and in Japan (Malina et al., 2004).

One of the factors influencing the stagnation or reduction in the motor skills of the present population is the growth in movement inactivity.

A whole series of epidemiological studies have shown that, during the static development of boys and girls, not only the habitual activity they are used to is decreasing, but also its volume and intensity (Kalman, Hamř́k, \& Pavelka, 2009; Kalman et al., 2011; Trost et al., 2002). Jadgo, Anderson, Baranowski, and Watson (2005) and Riddoch et al. (2007) have stated that many children and youth do not fulfill the current recommendations with regarding the health benefits of movement activity.

This negative trend is further confirmed by research showing a decrease in movement activity in children during the period of early school age, when important changes are occuring in the development of individuals and their relationship to lifelong movement activity in adulthood as well is formed (Goran, Gower, Nagy, \& Johnson, 1998; Kraut, Melamed, Gofer, \& Froom, 2003; Nader, Bradley, Houts, McRitchie, \& O’Brien, 2008).

The main cause of the decrease in habitual movement activities is an obvious trend to the predominance of a sedentary way of life (watching television, playing computer games, using transport to get to school and the like) in today's girls and boys (Arluk, Branch, Swain, \& Dowling, 2003; Bunc, 2008; Kalman et al., 2011; Sigmund \& Sigmundová, 2011).

If we consider the fact that we regard motoric tests to be indicators of the development and level of morphological and functional characteristics of individuals, this negative secular trend in motor skills together with the increase in overweight and obesity in the present population can also indicate a disturbance of the positive health of individuals and that also means in the population as a whole and is reflected in the gradual decrease in habitual movement activity (Avenell et al., 2004; Heyward \& Wagner, 2004; Pařízková et al., 2007; Przeweda \& Dobosz, 2005; Wilmore, Costill, \& Kenney, 2008).

The main aim of the research was to analyze and compare the static state and the level of motor skills of present-day Opole and Olomouc boys between the ages of 7 and 15; evaluate the level and dynamics of the height and weight of the Olomouc and Opole boys; and to compare the established values with the reference range of the 6th Nation-Wide Anthropological Survey of Children and Adolescents 2001 Czech Republic (6th CAV 2001) (Bláha et al., 2005). At the same time we wanted to carry out the evaluation of the individual performance of boys according to the UNIFITEST (6-60) test battery and compare their motoric output with that of boys of the same age in the Olomouc region between the years of 2001-2002 (Kopecký, 2006a).

\section{METHODS}

Transversal kinanthropological research projects which have made it possible to acquire anthropometric and motoric characterisation of boys aged from 7 to 15 years in the monitored set took place in the year 2010 at the same time in both the territory of the Olomouc region of the Czech Republic and in the Opole region of Poland. Overall, 1008 boys were measured. Of that number, there were 695 boys in the Olomouc region 
(who shall further be referred to with the abbreviation boys OLR) and 313 boys in the Opole region (who shall further be referred to as boys OPR). The research was carried out at basic schools in the Czech Republic and at basic schools and secondary grammar schools or college preparatory schools in Poland during standard instruction in physical education. The schools included in the research were selected using random sampling.

International comparison of the motor skills of children and youth is not easy, because investigative approaches are not completely compatible (Moravec, Kampmiller, \& Sedláček, 1996). A further problem in the evaluation of the motor skills of the monitored population is the fact that it is not possible to completely objectively rate the motoric performance in research projects of previous years due to the varying testing systems used. For these reasons we have decided to use a selection of motoric tests which make it possible to reliably compare the motoric output of boys from previous periods in the Olomouc region in the years 2001 and 2002 (Kopecký, 2006a).

The methodology of the research used by research teams in the Czech Republic and Poland was unified and standardized anthropometric methods (Bláha et al., 2005) and motoric tests were used (Měkota \& Blahuš, 1983; Měkota \& Novosad, 2005).

Boys were divided into age categories on the basis of the determination of the chronological age of each pupil, which was established on the date of the measurement in a decimal set with tenths of a year in accordance with the principles of the International Biological Program (Weiner \& Lourie, 1969).

Age categories were established according to WHO when the age categories were limited by the range in the number of years (for example, an 8 year old was anyone between the ages of 8.00 to 8.99 years).

For the establishment of physical height and weight, the methodology mentioned by Bláha et al. (2005) was used.

For the diagnostics of the level of the motoric output of boys, a complex battery of motoric tests was used - the standing long jump with legs together (testing the dynamic and explosive strength of the lower extremities), one-minute sit-ups (a dynamic test of the endurance and strength of the abdominal musculature and the lumbar-hip-thigh flexors), the $4 \times 10 \mathrm{~m}$ shuttle run (testing the speed of a subject running a course with a change of direction and partially also of their disposition to flexibility) and throwing a medicine ball with both hands (a dynamic test of the explosive strength of the upper limbs).

The tests were carried out in the gymnasium or sport hall of each school being used for the study under standard conditions.
The authors of the present paper, together with students of the relevant universities, measured the physical parameters and diagnosed the motor skills of the monitored sets of Olomouc and Opole boys using motor tests.

Statistical comparison was performed in accordance with Hendl (2004), in Statistica (version 10) software.

For statistical evaluation purposes, Student's $t$-test was used for one selection, with the help of which our sets were compared to population constants taken from referential sets of the 6th CAV 2001 (Bláha et al., 2005) and from the evaluation of the static and motoric development of boys and girls aged 7-15 in the Olomouc region (Kopecký, 2006a).

For the evaluation of the motoric level of the monitored sets of boys, $Z$-scores were also used and applied for the standardization of the measured values, that means the count of deviations of the measured values and the tested individuals from the referential data in the units of direction-setting variables (Kopecký, 2006a).

The evaluation of the motoric output of boys was carried out according to the standardized and unified test battery UNIFITTEST (6-60) (Měkota \& Kovář, 1996). For the comparison of the quantity of the presence of sets of Czech and Polish boys in individual categories of the UNIFITTEST (6-60), the nonparametric test $\chi^{2}$-test of good concurrence was used (Hend1, 2004).

For individual groups among those monitored, basic statistical characteristics were calculated - mean $(M)$ and standard deviation $(S D)$. Tests were carried out based on a $5 \%$ and a $1 \%$ level of significance $\left({ }^{*} p<.05\right.$ and $\left.{ }^{* *} p<.01\right)$.

\section{RESULTS}

The physical growth of the monitored sets of boys is characterized by the typical alternation of periods of increase followed by a decrease in the speed of the gaining of physical height and weight (Tables 1 and 2).

The dynamics of skeletal-linear growth in presentday Olomouc and Opole boys is presented, with the average values of their body height, in Table 1. As compared to the referential standards in the 6th CAV 2001 (Bláha et al., 2005), a significantly lower body height was found only in the following age categories - of Olomouc boys of 12 and 15 years and in Opole boys of 9 and 15 years of age.

Based on the comparison of the average values of their body height, it is apparent that their growth in height is nearly the same for both of the monitored groups of boys (Table 1). Between their 10th and 11th years, an increase in the growth of their body height was noted in both groups of the monitored sets of boys, 
which indicates a prepubertal growth spurt continuing in their subsequent growth period as well.

The period between the 12 th and the 15 th years is characterized by intensive height inrease. This pubertal growth spurt in boys is a result of the common influence of growth hormone with insulin - like growth factors I and II, and sex hormones (Malina et al., 2004). This growth spurt reaches its greatest growth speed in Olomouc and Opole boys between the ages of 12 and 13, where there is the largest additional growth in puberty with the peak of growth speed (PHV - Peak Height Velocity) reaching more than $8 \mathrm{~cm}$ per year. In all age groups of both Olomouc and Opole boys there is a concurrence in physical height, with the exception of the age category of 9 year old Olomouc boys, who grew $3 \mathrm{~cm}$ more in their physical height as compared with Opole boys of the same age (Table 1).

By means of the comparison of average values of the body weight of Olomouc and Opole boys with a referential standard of 6th CAV 2001 (Bláha et al., 2005), a corresponding body weight was found in all age categories (Table 2). A statistically lower body weight by, 3.2 $\mathrm{kg}$, against the reference standards of the 6th CAV 2001 was found only in 15 year old Olomouc boys (Table 2). The greatest interannual growth increment measured in body weight, that is in the so-called peak of the growth curves of body weight ( $P W V$ - Peak Weight Velocity), was discovered during the period of the growth spurt in Olomouc boys between the ages of 13 and 14 and made up $6 \mathrm{~kg}$. In the case of the Opole boys, a PWV was observed between 12 and 13 years of age and came to $7.76 \mathrm{~kg}$. In the boys of the 6th CAV 2001, the growth of body weight between the ages of 7 and 15 was observed to amount to $37.19 \mathrm{~kg}$. In the case of Olomouc boys it was 34.05 and in the case of Opole boys it made up $37.51 \mathrm{~kg}$ (Table 2).

The motoric test called the shuttle run $(\mathbf{4} \times \mathbf{1 0} \mathbf{m})$ evaluates speed and, partially, also flexibility. In this test, the sets of boys from both Olomouc and Opole had nearly the same results. A statistically significantly better performance was seen only in the case of the boys of 7 years of age from Opole (Table 3). The dynamics of the development of speed is similar in both sets of boys. The speed dynamics is gradually on the increase annually, while at the same time, a noticeable improvement in performance has been seen in Olomouc boys between the ages of 7 and 8 and in the period of pubertal acceleration between the ages of 13 and 14 .

The level of the dynamic and explosive strength of the lower extremities in boys and girls was evaluated by the motoric test called the standing long jump with legs together (Měkota \& Blahuš, 1983). The achieved results in boys demonstrate that performance between the ages of 7 and 15 is gradually improving. Table 4 shows that Opole boys in the group aged 9 to 11 reaches a statistically lower level of performance in the long jump from a standing long jump with legs together in comparison with boys of the same age from the Olomouc region. The dynamics of the development of dynamic strength demonstrates that the highest additional improvements in the standing long jump with legs together are, above all, to be observed during the period of the pubertal growth spurt.

Physical height plays a role in the improvement of performance, but, above all, a noticeable quantity of growth of the skeletal musculature, not only in percentages, but also in absolute values, plays a role in the overall mass and weight of the body (Malina et al., 2004).

At this time it is also possible to observe a higher level of the dynamic strength of the lower extremities in Opole boys, who achieve better results between the ages of 12 and 15 years of age. A statistically significant difference was found to the benefit of the Opole boys only in the age category of the 15 year olds (Table 4).

The highest performance improvement from one year to the next in the long jump occurred, with a length

Table 1

Comparison of body height (cm) of Olomouc and Opole boys with reference range of the 6th CAV 2001

\begin{tabular}{|c|c|c|c|c|c|c|c|c|c|}
\hline \multirow{2}{*}{$\begin{array}{l}\text { Age } \\
\text { (years) }\end{array}$} & \multicolumn{3}{|c|}{ Boys 6th CAV 2001} & \multicolumn{3}{|c|}{ Boys OLR } & \multicolumn{3}{|c|}{ Boys OPR } \\
\hline & $n$ & $M$ & $S D$ & $n$ & $M$ & $S D$ & $n$ & $M$ & $S D$ \\
\hline 7 & 1,129 & 128.39 & 5.92 & 74 & 128.21 & 5.24 & 23 & 129.79 & 6.86 \\
\hline 8 & 1,227 & 133.88 & 6.01 & 73 & 132.87 & 5.32 & 33 & 132.65 & 5.99 \\
\hline 9 & 1,367 & 138.92 & 6.26 & 69 & 139.07 & 5.79 & 31 & $136.06^{* *}$ & 7.00 \\
\hline 10 & 1,401 & 144.25 & 6.70 & 89 & 143.99 & 5.54 & 42 & 144.42 & 6.62 \\
\hline 11 & 1,494 & 149.66 & 7.25 & 77 & 150.34 & 6.69 & 36 & 148.63 & 6.70 \\
\hline 12 & 1,676 & 156.84 & 8.25 & 84 & $154.80 *$ & 8.95 & 49 & 155.47 & 8.42 \\
\hline 13 & 1,703 & 163.74 & 8.76 & 70 & 163.04 & 8.23 & 31 & 164.00 & 7.27 \\
\hline 14 & 1,447 & 171.03 & 8.55 & 86 & 169.56 & 8.70 & 32 & 171.72 & 7.53 \\
\hline 15 & 1,640 & 176.24 & 7.52 & 73 & $173.32 * *$ & 6.56 & 46 & $174.15^{*}$ & 6.41 \\
\hline
\end{tabular}

$* p<.05 . \quad * * p<.01$. 
Table 2

Comparison of the weight $(\mathrm{kg})$ of Olomouc and Opole boys with reference range of the 6th CAV 2001

\begin{tabular}{|c|c|c|c|c|c|c|c|c|c|}
\hline \multirow{2}{*}{$\begin{array}{l}\text { Age } \\
\text { (years) }\end{array}$} & \multicolumn{3}{|c|}{ Boys 6th CAV 2001} & \multicolumn{3}{|c|}{ Boys OLR } & \multicolumn{3}{|c|}{ Boys OPR } \\
\hline & $n$ & $M$ & $S D$ & $n$ & $M$ & $S D$ & $n$ & $M$ & $S D$ \\
\hline 7 & 1,130 & 27.03 & 5.06 & 74 & 27.15 & 4.68 & 23 & 29.13 & 6.39 \\
\hline 8 & 1,227 & 30.36 & 5.61 & 73 & 29.04 & 5.32 & 33 & 29.71 & 5.38 \\
\hline 9 & 1,367 & 33.55 & 6.97 & 69 & 35.19 & 8.17 & 31 & 33.76 & 7.38 \\
\hline 10 & 1,403 & 37.47 & 7.75 & 89 & 37.65 & 7.88 & 42 & 39.66 & 8.73 \\
\hline 11 & 1,495 & 41.34 & 9.01 & 77 & 42.94 & 10.47 & 36 & 42.34 & 10.23 \\
\hline 12 & 1,675 & 47.03 & 10.40 & 84 & 47.98 & 13.93 & 49 & 49.08 & 10.37 \\
\hline 13 & 1,704 & 52.43 & 10.98 & 70 & 53.59 & 12.16 & 31 & 56.84 & 13.15 \\
\hline 14 & 1,446 & 58.82 & 10.72 & 86 & 59.59 & 11.55 & 32 & 64.12 & 14.71 \\
\hline 15 & 1,638 & 64.22 & 10.62 & 73 & $61.20 *$ & 8.93 & 46 & 66.64 & 10.97 \\
\hline
\end{tabular}

$* p<.05$.

Table 3

Comparison of motor skills of Olomouc and Opole boys in the motor test $4 \times 10$ metre shuttle run $(\mathrm{s})$

\begin{tabular}{|c|c|c|c|c|c|c|c|}
\hline \multirow{2}{*}{$\begin{array}{l}\text { Age } \\
\text { (years) }\end{array}$} & \multicolumn{3}{|c|}{ Boys OLR } & \multicolumn{3}{|c|}{ Boys OPR } & \multirow{2}{*}{$\begin{array}{c}t \text {-test } \\
p\end{array}$} \\
\hline & $n$ & $M$ & $S D$ & $n$ & $M$ & $S D$ & \\
\hline 7 & 74 & 14.78 & 1.30 & 23 & 13.75 & 1.38 & $.002 * *$ \\
\hline 8 & 73 & 13.86 & 1.14 & 33 & 13.50 & 1.37 & .127 \\
\hline 9 & 69 & 13.21 & 1.10 & 31 & 13.00 & 1.30 & .174 \\
\hline 10 & 89 & 12.95 & 1.12 & 42 & 12.65 & 1.02 & .421 \\
\hline 11 & 77 & 12.40 & 0.91 & 36 & 12.54 & 1.00 & .974 \\
\hline 12 & 84 & 12.31 & 1.19 & 49 & 12.03 & 0.96 & .169 \\
\hline 13 & 70 & 12.21 & 1.07 & 31 & 12.21 & 1.06 & .333 \\
\hline 14 & 86 & 11.61 & 0.78 & 32 & 11.79 & 0.80 & .171 \\
\hline 15 & 73 & 11.53 & 1.19 & 46 & 11.45 & 0.70 & .878 \\
\hline
\end{tabular}

$* * p<.01$.

Table 4

Comparison of motor skills of Olomouc and Opole boys in the motor test standing long jump with legs together $(\mathrm{cm})$

\begin{tabular}{|c|c|c|c|c|c|c|c|}
\hline \multirow{2}{*}{$\begin{array}{l}\text { Age } \\
\text { (years) }\end{array}$} & \multicolumn{3}{|c|}{ Boys OLR } & \multicolumn{3}{|c|}{ Boys OPR } & \multirow{2}{*}{$\begin{array}{c}t \text {-test } \\
p\end{array}$} \\
\hline & $n$ & $M$ & $S D$ & $n$ & $M$ & $S D$ & \\
\hline 7 & 74 & 125.64 & 19.39 & 23 & 133.39 & 17.70 & .649 \\
\hline 8 & 73 & 133.82 & 18.94 & 33 & 127.76 & 19.46 & .133 \\
\hline 9 & 69 & 145.38 & 18.46 & 31 & 136.48 & 17.47 & $.026^{*}$ \\
\hline 10 & 89 & 145.83 & 18.81 & 42 & 146.88 & 16.70 & .401 \\
\hline 11 & 77 & 159.69 & 23.65 & 36 & 150.28 & 18.76 & $.038 *$ \\
\hline 12 & 84 & 160.80 & 26.40 & 49 & 161.73 & 24.72 & .838 \\
\hline 13 & 70 & 169.00 & 22.84 & 31 & 176.26 & 25.65 & .159 \\
\hline 14 & 86 & 188.81 & 23.28 & 32 & 198.06 & 29.81 & .079 \\
\hline 15 & 73 & 200.19 & 27.01 & 46 & 220.59 & 26.53 & $.001 * *$ \\
\hline
\end{tabular}

$* p<.05 . \quad * * p<.01$. 
of $19.81 \mathrm{~cm}$, in the Olomouc boys and was observed between the ages of 13 and 14, whereas in the set of Opole boys the measurement was of $22.53 \mathrm{~cm}$ between the ages of 14 and 15.

Table 5 presents the average values for the medicine ball throw with both hands into the distance in the cases of both Olomouc and Opole boys, which gradually increase between the ages of 7 and 15 .

The results have shown that the dynamic, explosive absolute strength of the upper limbs is, in Opole boys, statistically significantly higher in the age categories of 7, 10 and 15 year olds. The biggest difference is to be found in the medicine ball throw with both hands and is clear in the case of 15 year old boys. Opole boys throw, at the age of 15 years, $0.96 \mathrm{~cm}$ further than boys of the same age from the Olomouc region.
The strength of the abdominal musculature in boys was evaluated with the help of the one minute sit-up motoric test. The number of repeated cycles in the abovementioned test increases with age (Table 6). Most advances in the number of repetitions increased between 7 and 11 years of age among Olomouc boys, whereas in the case of Opole boys this occurred between their 7 th and the 13th year of age. Following this burst of growth, the stagnation of performance is clear. The advances are low in comparison with previous periods.

It is interesting that the difference in the period between their 7th and 11th year, when Olomouc boys in all age categories reach statistically significantly better performance in the sit-up test. From their 12th year, the performance of Olomouc and Opole boys is nearly the same (Table 6).

Table 5

Comparison of motor skills of Olomouc and Opole boys in the test throwing the medicine ball using both hands $(m)$

\begin{tabular}{|c|c|c|c|c|c|c|c|}
\hline \multirow{2}{*}{$\begin{array}{l}\text { Age } \\
\text { (years) }\end{array}$} & \multicolumn{3}{|c|}{ Boys OLR } & \multicolumn{3}{|c|}{ Boys OPR } & \multirow{2}{*}{$\begin{array}{c}t \text {-test } \\
p\end{array}$} \\
\hline & $n$ & $M$ & $S D$ & $n$ & $M$ & $S D$ & \\
\hline 7 & 74 & 2.41 & 0.50 & 23 & 3.01 & 0.94 & $<.001^{* *}$ \\
\hline 8 & 73 & 2.84 & 0.55 & 33 & 2.87 & 0.62 & .403 \\
\hline 9 & 69 & 3.50 & 0.65 & 31 & 3.42 & 0.85 & .604 \\
\hline 10 & 89 & 3.86 & 0.70 & 42 & 4.32 & 0.75 & $.001^{* *}$ \\
\hline 11 & 77 & 4.44 & 0.90 & 36 & 4.34 & 0.77 & .569 \\
\hline 12 & 84 & 5.02 & 1.12 & 49 & 5.05 & 1.18 & .865 \\
\hline 13 & 70 & 6.03 & 1.45 & 31 & 5.82 & 1.18 & .476 \\
\hline 14 & 86 & 7.12 & 1.42 & 32 & 7.38 & 1.60 & .384 \\
\hline 15 & 73 & 7.53 & 1.42 & 46 & 8.49 & 1.58 & $.001^{* *}$ \\
\hline
\end{tabular}

$* * p<.01$.

Table 6

Comparison of motor skills of Olomouc and Opole boys in the motor test sit-ups during a l-minute period (number)

\begin{tabular}{|c|c|c|c|c|c|c|c|}
\hline \multirow{2}{*}{$\begin{array}{l}\text { Age } \\
\text { (years) }\end{array}$} & \multicolumn{3}{|c|}{ Boys OLR } & \multicolumn{3}{|c|}{ Boys OPR } & \multirow{2}{*}{$\begin{array}{c}t \text {-test } \\
p\end{array}$} \\
\hline & $n$ & $M$ & $S D$ & $n$ & $M$ & $S D$ & \\
\hline 7 & 74 & 25.57 & 7.60 & 23 & 16.78 & 2.58 & $<.001 * *$ \\
\hline 8 & 73 & 30.79 & 8.73 & 33 & 23.36 & 6.60 & $<.001^{* *}$ \\
\hline 9 & 69 & 32.52 & 9.20 & 31 & 27.19 & 6.04 & $.004 * *$ \\
\hline 10 & 89 & 34.82 & 7.75 & 42 & 27.79 & 7.23 & $<.001 * *$ \\
\hline 11 & 77 & 37.44 & 9.01 & 36 & 29.92 & 7.22 & $<.001^{* *}$ \\
\hline 12 & 84 & 37.07 & 8.61 & 49 & 35.14 & 8.52 & .213 \\
\hline 13 & 70 & 38.86 & 8.20 & 31 & 39.74 & 5.47 & .585 \\
\hline 14 & 86 & 40.30 & 7.28 & 32 & 41.72 & 8.53 & .372 \\
\hline 15 & 73 & 41.34 & 9.65 & 36 & 43.61 & 7.00 & .171 \\
\hline
\end{tabular}

$* * p<.01$. 
For the verification of individual motor skills of Olomouc and Opole boys, the UNIFITTEST (6-60) test battery was used. The UNIFITTEST (6-60) test battery, as presented by Měkota and Kovář (1996), is a well-worked out system of evaluation, meant for individual and group diagnostics of motoric performance. In the presented test battery, UNIFITTEST (6-60), standards which have been set for factual and functional reasons are present. Output limits are set up according to gender, age and the state of an individual's organism.

For the evaluation of motoric performance of individual boys, the standardized test battery, UNIFITTEST (6-60) was used, including the following tests - the $4 \times 10 \mathrm{~m}$ shuttle run for boys in the age category between 7 and 14 [note: the norms mentioned in the UNIFITTEST (6-60) do not mention any evaluation of 15 year old boys], one-minute sit-ups and the standing long jump with legs together for boys between the ages of 7 and 15 .

These tests, with their description and the way in which they are carried out are in concordance with other test batteries used and carried out in the course of doing this research.

The evaluation of individual motoric performance was carried out in all age categories in the monitored sets. In Table 7 and 8, we present the summarized results of the evaluation of the already-mentioned free motoric tests. For the evaluation of the quantitative performance of boys in individual categories of the
UNIFITTEST (6-60) in accordance with the achieved motoric performance of the monitored sets of boys, the nonparametric test of good concurrence $\chi^{2}$ was used.

From the point of view of the performance of individual boys in the evaluative categories of the UNIFITTEST (6-60) it was determined that, overall, Olomouc boys achieved weaker performance levels in the motoric test called the $4 \times 10 \mathrm{~m}$ shuttle run in comparison with Opole boys $\left(\chi^{2}=9.495^{*}\right)$. In the long jump, no statistically significant differences in the performance of boys in the authorized categories of the UNIFITTEST (6-60) were discovered.

In the motoric one minute sit-up test, a higher quantity of the output of the Olomouc boys in the above average category and their noticeably above average output was found. On the other hand, Opole boys had a higher quantity of their output in the below average performance category of the authorized categories of the UNIFITTEST $\left(\chi^{2}=61.327 * *\right)$.

The fact that, altogether, $38.97 \%$ of the Olomouc boys and $41.60 \%$ of the Opole boys have a below average level of motor skills is clear, based on the categorization of the monitored sets of boys into individual performance categories of the UNIFITTEST (6-60), which inform us about the level of the development of their motor skills, endurance, speed and strength capabilities and shows the inadequate development of the tested skills. If we consider the fact that the listed motor skills are regarded as the basis of physical fitness, then the results we have found are not positive.

Table 7

The categorization of Olomouc boys into the performance categories of the UNIFITTEST (6-60)

\begin{tabular}{|c|c|c|c|c|c|c|c|c|c|c|c|}
\hline \multirow[b]{2}{*}{ Motoric test } & \multirow[b]{2}{*}{$n$} & \multicolumn{2}{|c|}{$\begin{array}{c}\text { Noticeably below } \\
\text { average }\end{array}$} & \multicolumn{2}{|c|}{ Below average } & \multicolumn{2}{|c|}{ Average } & \multicolumn{2}{|c|}{ Above average } & \multicolumn{2}{|c|}{$\begin{array}{c}\text { Noticeably above } \\
\text { average }\end{array}$} \\
\hline & & $n$ & $\%$ & $n$ & $\%$ & $n$ & $\%$ & $n$ & $\%$ & $n$ & $\%$ \\
\hline Shuttle run & 622 & 164 & 26.37 & 161 & 25.88 & 187 & 30.06 & 99 & 15.92 & 11 & 1.77 \\
\hline Long jump & 695 & 115 & 16.55 & 202 & 29.06 & 237 & 34.10 & 121 & 17.41 & 18 & 2.59 \\
\hline Sit-up & 695 & 26 & 3.74 & 116 & 16.69 & 294 & 42.30 & 208 & 29.93 & 51 & 7.34 \\
\hline Together & 2,012 & 305 & 15.16 & 479 & 23.81 & 718 & 35.68 & 428 & 21.27 & 80 & 3.98 \\
\hline
\end{tabular}

Table 8

The categorization of Opole boys into the performance categories of the UNIFITTEST (6-60)

\begin{tabular}{|c|c|c|c|c|c|c|c|c|c|c|c|}
\hline \multirow[b]{2}{*}{ Motoric test } & \multirow[b]{2}{*}{$n$} & \multicolumn{2}{|c|}{$\begin{array}{c}\text { Noticeably below } \\
\text { average }\end{array}$} & \multicolumn{2}{|c|}{ Below average } & \multicolumn{2}{|c|}{ Average } & \multicolumn{2}{|c|}{ Above average } & \multicolumn{2}{|c|}{$\begin{array}{c}\text { Noticeably above } \\
\text { average }\end{array}$} \\
\hline & & $n$ & $\%$ & $n$ & $\%$ & $n$ & $\%$ & $n$ & $\%$ & $n$ & $\%$ \\
\hline Shuttle run & 277 & 49 & 17.69 & 74 & 26.71 & 91 & 32.85 & 55 & 19.86 & 8 & 2.86 \\
\hline Long jump & 323 & 53 & 16.41 & 98 & 30.34 & 92 & 28.48 & 64 & 19.81 & 15 & 4.64 \\
\hline Sit-up & 323 & 7 & 2.17 & 103 & 31.89 & 139 & 43.03 & 59 & 18.27 & 11 & 3.41 \\
\hline Together & 923 & 109 & 11.81 & 275 & 29.79 & 322 & 34.89 & 178 & 19.28 & 34 & 3.68 \\
\hline
\end{tabular}




\section{DISCUSSION}

Sufficient attention is paid to the evaluation of the static development of children and youth in the Czech Republic thanks to nationwide anthropological research, which was regularly carried out starting in the year 1951 and continuing through the year 2001, when the last research project of a nationwide character was carried out (Bláha et al., 2005).

The most recent research project focussed on the evaluation of the motoric performance of youth between the age of 7 and 18 took place in 1987 (Moravec et al., 1990).

Since that time no nationwide research has been carried out in the Czech Republic focussed on the evaluation of the motoric performance of the population. For these reasons we decided to evaluate the motoric performance of the monitored sets of participants based on comparison with referential data, which are mentioned by Kopecký (2006a). The presented data were taken from an anthropological research project which took place in the Olomouc region in the years 2001 and 2002.

Kopecký (2006a) states that the monitored set of boys showed, from the point of view of comparing the physical height and mass, compatible parameters, as they were presented by the nationwide norms of the 6th nationwide anthropological research project of the year 2001 (Bláha et al., 2005). Considering the fact that the sets of monitored Olomouc and Opole boys have shown themselves to have nearly the same average values in comparison with the 6th nationwide anthropological research project (Table 1 and 2), we can say that, similarly to the statistic parameters listed as being compatible with the average values of Olomouc boys from the years 2001 and 2002 (further referred to as OL 2002).
An indicator of the speed is the $\mathbf{4} \times \mathbf{1 0} \mathbf{~ m}$ shuttle run, which, in addition to measuring speed, also partially provides information about flexibility. As we can see based on the results of the measurements, the development of speed in Olomouc and Opole boys is not the same as compared to the referential set of Olomouc boys from the year 2002 .

When evaluating motoric performance, differing performance parameters were demonstrated. Table 9 and Figure 1 show that Olomouc boys in the year 2010 (Boys OLR) reached, in this motoric test, in all age categories, significantly lower performance levels.

Weaker performance was also found in the age category of Olomouc boys of 9 and 11 years of age, but the presented differences are not statistically significant. Similarly, also boys from Poland (Boys OPR) reach a lower level of motoric performance, but statistically significant differences were found in the categories of boys between the ages of 13 and 15 (Table 9, Figure 1).

Figure 1 presents the comparison of the results achieved by Olomouc and Opole boys with referential data for the Olomouc boys from the years 2001-2002 (Kopecký, 2006a) with the help of $Z$-scores. From the calculated $Z$-scores it is clear that the results are in the zones of the average and below-average development of speed in both Olomouc and Opole boys (comment: in Figure 1 where we see the calculated $Z$-scores, the listed values have been displayed in such a way as to make clear the comparison of results in the sense of better or worse times; that means that in the $4 \times 10 \mathrm{~m}$ shuttle run test, a higher time reset actually means a worse level of performance when compared to referential values).

It is clear by looking at Figure 1 that, in the period when boys are a bit older, we can see in both sets of boys a tendency to the worsening of their speed in com-

Table 9

Comparison of motor skills of Olomouc and Opole boys in the motor test $4 \times 10$ metre shuttle run (s) with the 2002 reference data

\begin{tabular}{|c|c|c|c|c|c|c|c|c|c|}
\hline \multirow{2}{*}{$\begin{array}{l}\text { Age } \\
\text { (years) }\end{array}$} & \multicolumn{3}{|c|}{ Boys OL 2002} & \multicolumn{3}{|c|}{ Boys OLR } & \multicolumn{3}{|c|}{ Boys OPR } \\
\hline & $n$ & $M$ & $S D$ & $n$ & $M$ & $S D$ & $n$ & $M$ & $S D$ \\
\hline 7 & 67 & 13.53 & 1.07 & 74 & $14.78^{* *}$ & 1.30 & 23 & 13.75 & 1.38 \\
\hline 8 & 64 & 13.05 & 1.03 & 73 & $13.86^{* *}$ & 1.14 & 33 & 13.50 & 1.37 \\
\hline 9 & 64 & 13.04 & 1.09 & 69 & 13.21 & 1.10 & 31 & 13.00 & 1.30 \\
\hline 10 & 83 & 12.67 & 1.05 & 89 & $12.95^{*}$ & 1.12 & 42 & 12.65 & 1.02 \\
\hline 11 & 72 & 12.49 & 1.19 & 77 & 12.40 & 0.91 & 36 & 12.54 & 1.00 \\
\hline 12 & 78 & 11.78 & 0.82 & 84 & $12.31 * *$ & 1.19 & 49 & 12.03 & 0.96 \\
\hline 13 & 68 & 11.36 & 0.69 & 70 & $12.21^{* *}$ & 1.21 & 31 & $12.21 * *$ & 1.06 \\
\hline 14 & 67 & 11.24 & 0.71 & 86 & $11.61 * *$ & 0.78 & 32 & $11.79 * *$ & 0.80 \\
\hline 15 & 57 & 11.01 & 0.54 & 73 & $11.53 * *$ & 1.19 & 36 & $11.49 * *$ & 0.70 \\
\hline
\end{tabular}

$* p<.05 . \quad * * p<.01$. 


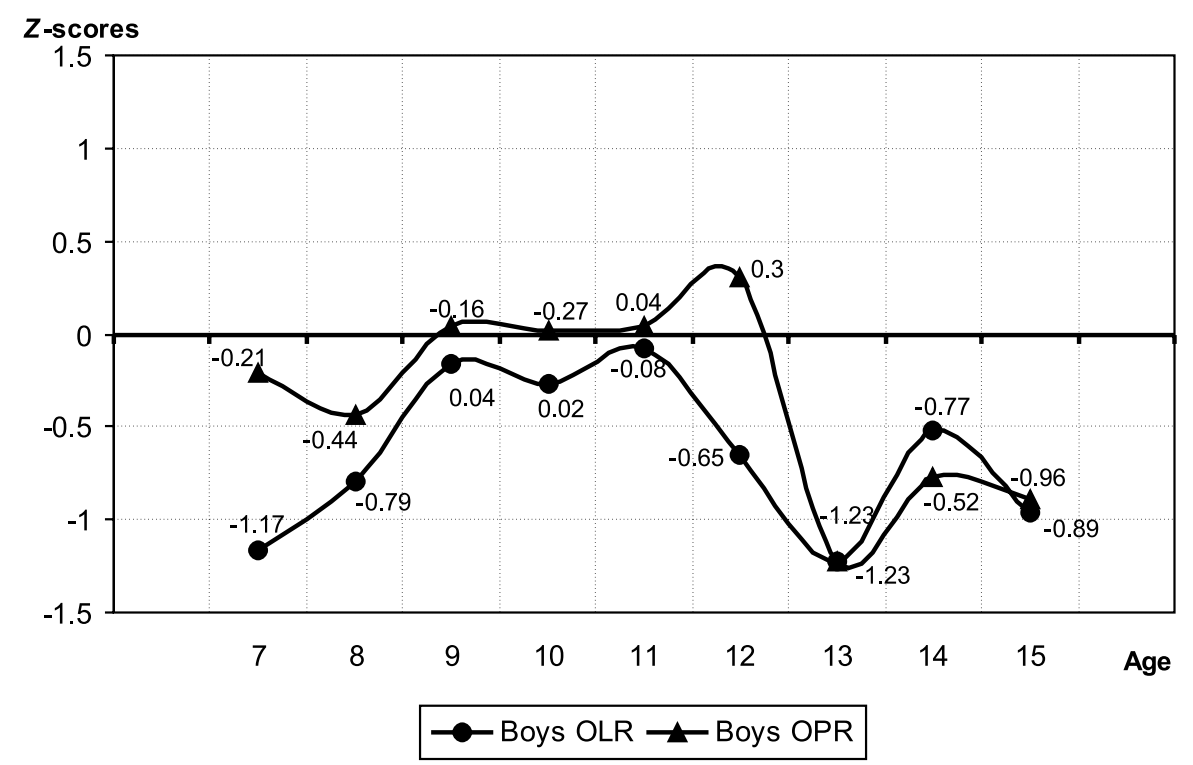

Figure 1. Comparison of motor skills of Olomouc and Opole boys in the motor test $4 \times 10$ metre shuttle run (s) with the 2002 reference data, using $Z$-score

parison with the referential data from the years 20012002 (Kopecký, 2006a).

In the motoric test medicine ball throw using both hands has been detected a statistically lower performance level in the dynamic, absolute explosive strength ablities of the upper limbs in Olomouc boys in the age category from 7 to 11 years and in 15 year olds. In the case of the Opole boys this is true for boys in the age categories 8, 11 and 13 years of age (Table 10).

On the other hand, 15 year old boys from Opole have a dynamic and explosive strength in their upper limbs at a higher level in comparison with the referential values of the year 2002 (Kopecký, 2006a).

In spite of the fact that the calculated values of the $Z$-scores are found within the $\pm 0.75 \mathrm{SD}$ zone, overall they show lower performance results achieved, above all by Olomouc boys (Boys OLR), in comparison with boys from the years 2001-2002 (Table 10, Figure 2).

Performance levels in relative dynamic and explosive strength of the lower extremities in the standing long jump with legs together in Olomouc and Opole boys are presented by Table 11 a Figure 3. From these results it is clear that present-day Olomouc boys reach a lower performance level in comparison with their contemporaries of the same age from the Olomouc region in the years 2001-2002 (Kopecký, 2006a). Only in the age categories of 11,14 and 15 year olds were no statistically significant differences found. Similarly, even Opole boys have a worse performance level in the standing long jump with legs together in the age categories from 8 to 13 years of age. Only in the age category of the 15 year old Opole boys was a statistically better performance found in comparison with referential data for Olomouc boys from the year 2002 (Kopecký, 2006a) (Table 11, Figure 3). The calculated values of the $Z$-scores show a tendency to the worsening of $d y-$ namic and explosive strength of the lower extremities in both monitored sets of boys, especially in the set of Olomouc boys (Boys OLR) (Figure 3).

In comparison with the average performance levels of Olomouc and Opole boys with referential data mentioned by Kopecký (2006a) from the years 2001 and 2002, it is apparent that the monitored sets of boys have lower performance levels for their speed and their dynamic, explosive-strength of their upper and lower extremities. A lower performance level is more clearly to be seen in the monitored set of the Olomouc boys from the year 2010 .

Similar findings are reported by Jopkiewicz, Lelonek, and Kopecký (2013), who present the results of a comparison of motor skills of boys aged 7 to 16 from the Kielce region (Poland) and the Olomouc region (Czech Republic). Based on the results they conclude that the monitored sets of boys demonstrate the same motor skills in the test standing long jump with legs together. In the tests $4 \times 10$ metre shuttle run and throwing the medicine ball using both hands, the Olomouc and the Kielce boys achieve the same motor score within the 7 to 11 age group; however, from age 12 to 16 , the Kielce boys achieve a higher motor score than the Olomouc region boys from the same age group.

\section{CONCLUSIONS}

Anthropometrics and the testing of motoric performance levels of present-day 7-15 year old Olomouc 
Table 10

Comparison of motor skills of Olomouc and Opole boys in the test throwing the medicine ball using both hands $(\mathrm{m})$ with the 2002 reference data

\begin{tabular}{|c|c|c|c|c|c|c|c|c|c|}
\hline \multirow{2}{*}{$\begin{array}{l}\text { Age } \\
\text { (years) }\end{array}$} & \multicolumn{3}{|c|}{ Boys OL 2002} & \multicolumn{3}{|c|}{ Boys OLR } & \multicolumn{3}{|c|}{ Boys OPR } \\
\hline & $n$ & $M$ & $S D$ & $n$ & $M$ & $S D$ & $n$ & $M$ & $S D$ \\
\hline 7 & 67 & 2.79 & 0.61 & 74 & $2.41 * *$ & 0.50 & 23 & 3.01 & 0.94 \\
\hline 8 & 64 & 3.20 & 0.67 & 73 & $2.84 * *$ & 0.55 & 33 & $2.87 * *$ & 0.62 \\
\hline 9 & 64 & 3.68 & 0.85 & 69 & $3.50 *$ & 0.65 & 31 & 3.42 & 0.85 \\
\hline 10 & 83 & 4.21 & 0.72 & 89 & $3.86 * *$ & 0.70 & 42 & 4.32 & 0.75 \\
\hline 11 & 72 & 4.78 & 0.95 & 77 & $4.44 * *$ & 0.90 & 36 & $4.34 * *$ & 0.77 \\
\hline 12 & 78 & 5.25 & 1.02 & 84 & 5.02 & 1.12 & 49 & 5.05 & 1.18 \\
\hline 13 & 68 & 6.26 & 1.12 & 70 & 6.03 & 1.45 & 31 & $5.82 *$ & 1.18 \\
\hline 14 & 67 & 7.12 & 1.58 & 86 & 7.12 & 1.42 & 32 & 7.38 & 1.60 \\
\hline 15 & 57 & 7.96 & 1.50 & 73 & $7.53 * *$ & 1.42 & 36 & $8.42 *$ & 1.56 \\
\hline
\end{tabular}

${ }^{*} p<.05 . \quad * * p<.01$.

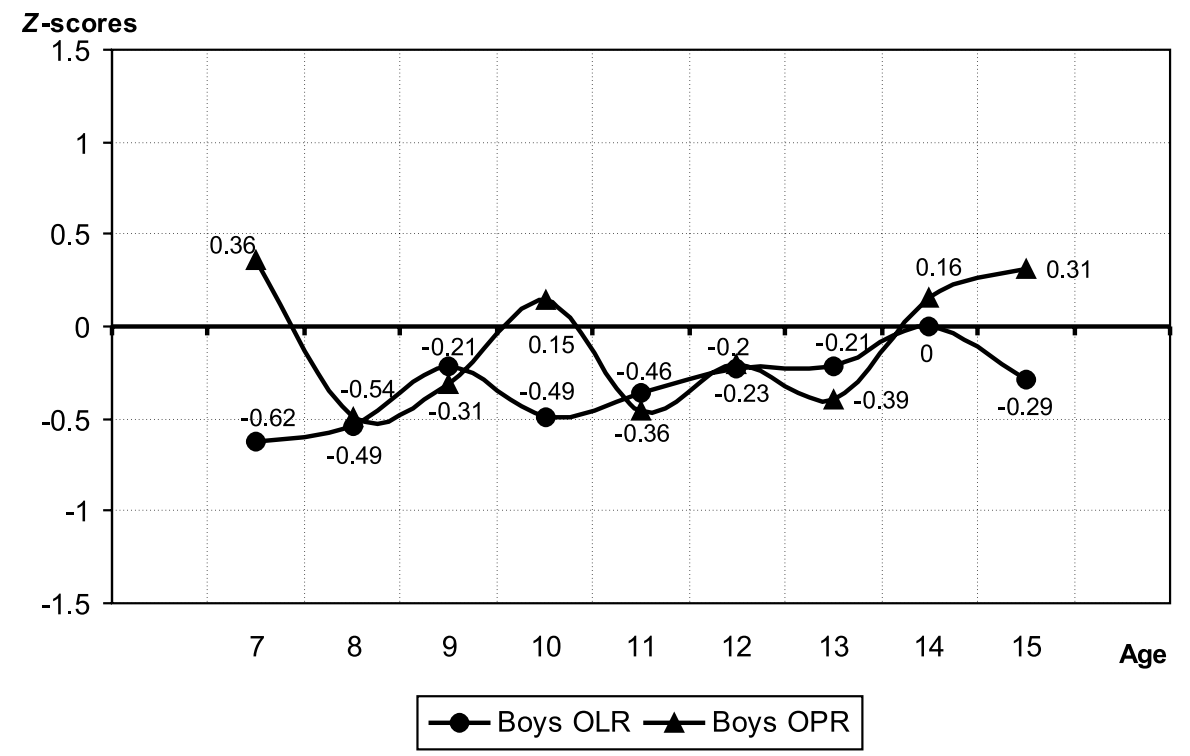

Figure 2. Comparison of motor skills of Olomouc and Opole boys in the test throwing the medicine ball using both hands (m) with the 2002 reference data, using $Z$-score

and Opole boys have shown that, among the monitored sets, no differences in physical height and weight were found. The somatic parameters of the boys correspond to the nationwide norms of 6th CAV 2001 as well as the somatic parameters of Olomouc boys from the year 2001 and 2002. Similar performance levels were reached by both sets in speed and in the dynamic explosive strength of the lower limbs. A lower performance level in comparison with Opole boys was reached by Olomouc boys in throwing the medicine ball using both hands. On the other hand, in the early school age period, Olomouc boys have a better-developed level of endurance-strength of their abdominal musculature. The evaluation of the individual motoric performance of boys in accordance with the heterogeneous test bat- tery UNIFITTEST (6-60) showed overall that nearly $39 \%$ of the Olomouc and $42 \%$ of the Opole boys have below average to noticeably below average motoric performance, which signals the insufficient development of the tested skills. The comparison of the tested results of the present-day Olomouc and Opole boys with referential data of Olomouc boys from the years 2001 and 2002 have shown a decrease in speed, endurancestrength of the abdominal musculature and the dynamic-explosive power of the upper and lower limbs.

Probably we are seeing insufficient habitual movement activity of present-day boys, which reflects negative trends in the decrease of movement activity and a predominating sedentary way of life in the general population. 
Table 11

Comparison of motor skills of Olomouc and Opole boys in the motor test standing long jump with legs together $(\mathrm{cm})$ with the 2002 reference data

\begin{tabular}{|c|c|c|c|c|c|c|c|c|c|}
\hline \multirow{2}{*}{$\begin{array}{l}\text { Age } \\
\text { (years) }\end{array}$} & \multicolumn{3}{|c|}{ Boys OL 2002} & \multicolumn{3}{|c|}{ Boys OLR } & \multicolumn{3}{|c|}{ Boys OPR } \\
\hline & $n$ & $M$ & $S D$ & $n$ & $M$ & $S D$ & $n$ & $M$ & $S D$ \\
\hline 7 & 67 & 131.83 & 17.18 & 74 & $125.64 * *$ & 19.39 & 23 & 133.39 & 17.70 \\
\hline 8 & 64 & 142.15 & 18.55 & 73 & $133.82 * *$ & 18.94 & 33 & $127.76^{* *}$ & 19.46 \\
\hline 9 & 64 & 150.50 & 20.93 & 69 & $145.38 *$ & 18.46 & 31 & $136.48 * *$ & 17.47 \\
\hline 10 & 83 & 153.37 & 18.87 & 89 & $145.83^{* *}$ & 18.81 & 42 & $146.88^{*}$ & 16.70 \\
\hline 11 & 72 & 164.18 & 19.06 & 77 & 159.69 & 23.65 & 36 & $150.28 * *$ & 18.76 \\
\hline 12 & 78 & 171.79 & 16.64 & 84 & $160.80 * *$ & 26.40 & 49 & $161.73 * *$ & 24.72 \\
\hline 13 & 68 & 181.77 & 19.05 & 70 & $169.00 * *$ & 22.84 & 31 & 176.26 & 25.65 \\
\hline 14 & 67 & 192.39 & 23.65 & 86 & 188.81 & 23.28 & 32 & 198.06 & 29.80 \\
\hline 15 & 57 & 205.65 & 18.75 & 73 & 200.19 & 27.01 & 36 & $221.03 * *$ & 25.43 \\
\hline
\end{tabular}

$* p<.05 . \quad * * p<.01$.

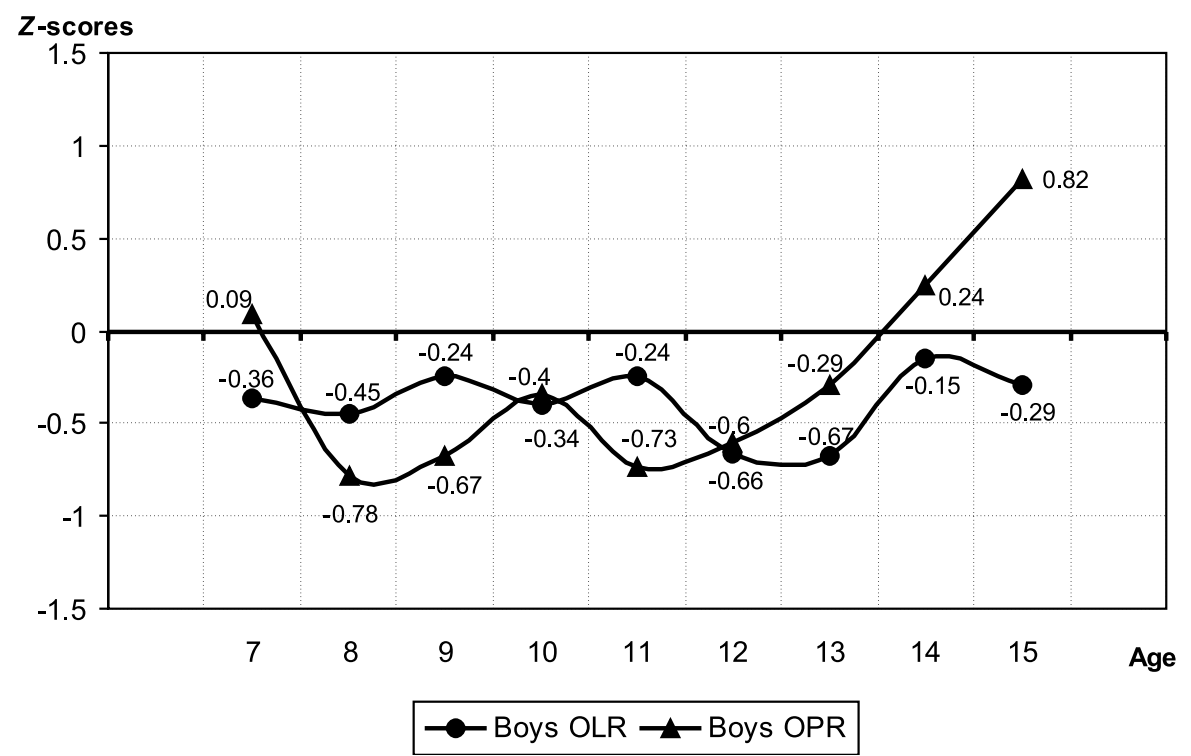

Figure 3. Comparison of motor skills of Olomouc and Opole boys in the motor test standing long jump with legs together $(\mathrm{cm})$ with the 2002 reference data, using Z-score

\section{REFERENCES}

Arluk, S. L., Branch, J. D., Swain, D. P., \& Dowling, E. A. (2003). Childhood obesity's relationship to time spent in sedentary behavior. Military Medicine, 168, 583-586.

Asienkiewicz, R. (2007). Ontogenetyczna zmienność rozwoju fizycznego i motorycznego chlopców i dziewczat $w$ wieku 5-14 lat [Ontogenetic variation of physical and motor development of boys and girls aged 5-14 years]. Zielona Góra: Uniwersytet Zielonogórski.

Avenell, A., Broom, J., Brown, T. J., Poobalan, A., Aucott, L., Stearns, ... Grant, A. M. (2004). Systematic review of the long-term effects and economic consequences of treatments for obesity and implications for health improvement. Health Technology Assessment, 8(11), 1-182.

Bláha, P., Susanne, C. H., Rebato, E., Bernis, C., Eliášová, H., Marrodán, D., ... Vignerová, J. (2007). Essentials of biological anthropology (selected chapters). Praha: Karolinum.

Bláha, P., Vignerová, J., Riedlová, J., Kobzová, J., Krejčovský, L., \& Brabec, M. (2005). 6. celostátní antropologický výzkum dětí a mládeže 2001, Česká republika [6th Nation-wide Anthropological Survey of Children and Adolescents 2001 Czech Republic]. Praha: SZÚ. 
Bodzsár, E. B., \& Sussane, C. H. (1998). Secular growth changes in Europe. Budapest: Eötvös University Press.

Bunc, V. (2008). Nadváha a obezita dětí - životní styl jako příčina a důsledek [Overweight and obesity in children - life style as a cause and consequence]. Česká kinantropologie, 12(3), 61-69.

Frömel, K., Novosad, J., \& Svozil, Z. (1999). Pohybová aktivita a sportovní zájmy mládeže [Physical activity and sporting interests of young people]. Olomouc: Univerzita Palackého.

Goran, M. I., Gower, B. A., Nagy, T. R., \& Johnson, R. K. (1998). Developmental changes in energy expenditure and physical activity in children: Evidence for a decline in physical activity in girls before puberty. Pediatrics, 101, 887-891.

Hendl, J. (2004). Přehled statistických metod zpracování dat. Analýza a metaanalýza dat [Overview of statistical methods for data processing. Analysis and meta-analysis of data]. Praha: Portál.

Heyward, V. H., \& Wagner, D. R. (2004). Applied body composition assessment. Champaign, IL: Human Kinetics.

Hirtz, P. (2007). Phänomene der motorischen Entwicklung des Menschen [Phenomena of motor development of the human]. Schorndorf: Hofmann.

Jadgo, R., Anderson, C. B., Baranowski, T., \& Watson, K. (2005). Adolescent patterns of physical activity differences by gender, day, and time of day. American Journal of Preventive Medicine, 28, 447-452.

Jančoková, L., Kremnický, J., Misárošová, M., Mišurová, D., \& Kompán, J. (2002). Telesný a funkčný rozvoj žiakov základných škôl v Banskobystrickom kraji: Monitorovanie telesného rozvoja, funkčného stavu a pohybovej výkonnosti žiakov základných škôl v Banskobystrickom kraji na začiatku nového tisícročia [Physical and functional development of the basic school pupils in the district of Banska Bystrica: Monitoring of physical development, functional state and motional efficiency of students from basic school in the district of Banska Bystrica in the beginning of the new millenary]. Banská Bystrica: Fakulta humanitných vied Univerzity Mateja Bela.

Jopkiewcicz, A., Lelonek, M., \& Kopecký, M. (2013). Analiza porównawcza sprawności motorycznej dzieci i mlodzieźy polskiej i czeskiej [Comparative analysis of motor skills in Polish and Czech children and adolescents]. In A. Jopkiewicz \& S. Nowak (Eds.), Uwarunkowania zdrowia i rozwoju dzieci $i$ mlodziezy-implikacje badawcze $i$ rekomendace praktyczne (pp. 53-70). Radom: Institut Technologii Eksploatacji-Państwowy Instytut Badawczy.

Jopkiewcicz, A., Przychodni, A., Jopkiewizc, A., \& Krzystanek, K. (2011). Pozytywne wskaźniki zdrowia dzieci i mlodzieźy kielckej [The positive indicators of the health of children and young people in Kielce]. Kielce: Institut technologii Eksploatacji-Państwowy Instytut Badawczy, Radom: Wydzial Pedagogiczny i Aetystyczny UJK.

Kalman, M., Hamř́k, Z., \& Pavelka, J. (2009). Podpora pohybové aktivity pro odbornou veřejnost [Promoting physical activity for professional public]. Olomouc: ORE-institut.

Kalman, M., Sigmund, E., Sigmundová, D., Hamřík, Z., Beneš, L., Benešová, D., \& Csémy, L. (2011). Národní zpráva o zdraví a životním stylu dětí a školá$k \dot{u}$ [The national report on health and lifestyle of children and schoolchildren]. Olomouc: Univerzita Palackého.

Kopecký, M. (2006a). Somatický a motorický vývoj 7 až 15letých chlapců a divek v olomouckém regionu [Somatic and motoric development of 7-15 year-old boys and girls in Olomouc region]. Olomouc: Univerzita Palackého.

Kopecký, M. (2006b). The secular trend in the somatic development and motoric performance of boys in the Olomouc region within the last 36 years. Acta Universitatis Palackianae Olomucensis. Gymnica, 36(3), 55-64.

Kraut, A., Melamed, S., Gofer, D., \& Froom, P. (2003). Effect of school age sports on leisure time physical activity in adults: The CORDIS study. Medicine and Science in Sports and Exercise, 35, 2038-2042.

Lobstein, T., Baur, L., \& Uauy, R. (2004). Obesity in children and young people: A crisis in public health. Report to the WHO International Obesity Task Force. Obesity Reviews, 5(Suppl. 1), 5-104.

Lobstein, T., \& Frelut, L. (2003). Prevalence of overweight among children in Europe. Obesity Reviews, 4, 195-200.

Malina, R. M., Bouchard, C., \& Bar-Or, O. (2004). Growth, maturation, and physical activity. Champaign, IL: Human Kinetics.

Měkota, K., \& Blahuš, P. (1983). Motorické testy $v$ tělesné výchově [The motor tests in physical education]. Praha: Státní pedagogické nakladatelství.

Měkota, K., \& Kovář, R. (1996). UNIFITTEST (6-60). Manuál pro hodnocení základní motorické výkonnosti a vybraných charakteristik tělesné stavby mládeže a dospělých v České republice [UNIFITTEST (6-60). Manual for the assessment of basic motor performance and body composition of selected characteristics of youth and adults in the Czech Republic]. Ostrava: Ostravská univerzita.

Měkota, K., \& Novosad, J. (2005). Motorické schopnosti [Motor skills]. Olomouc: Univerzita Palackého. 
Moravec, R., Havliček, I., Kasa, J., Ramcsay, L., Scholzová, A., Šelingerová, M., Štulrajeter, V., \& Zapletalová, L. (1990). Telesný, funkčný rozvoj a pohybová výkonnost' 7-18ročnej mládeže v ČSFR [The physical and functional development and motor performance in 7-18 year old Czecho-Slovak youth]. Bratislava: Ministerstvo školstva, mládeže a športu SROV.

Moravec, R., Kampmiller, T., Sedláček, J. (1996). EUROFIT. Telesný rozvoj a pohybová výkonnost' školskej populácie na Slovensku [EUROFIT: Physical development and motor performance of the Slovak school youth]. Bratislava: Slovenská vedecká spoločnost’ pre telesnú výchovu a šport.

Nader, P. R., Bradley, R. H., Houts, R. M., McRitchie, S. I., \& O'Brien, M. (2008). Moderate to vigorous physical activity from ages 9 to 15 years. Journal of the American Medical Association, 300, 295-305.

Pařízková, J., Lisá, L., Bláha, P., Fraňková, S., Hainerová, I., Hlavatá, K., ... Vignerová, J. (2007). Obezita v détství a dospívání [Obesity in childhood and adolescence]. Praha: Galén \& Karolinum.

Przeweda, R., \& Dobosz, J. (2005). Growth and physical fitness of Polish youths. Warszaw: AWF.

Riddoch, C. J., Mattocks, C., Deere, K., Saunders, J., Kirkby, J., Tiling, K., ... Ness, A. R. (2007). Objective measurement of levels and paterns of physical activity. Archives of Disease in Childhood, 92, 963-969.

Sigmund, E., \& Sigmundová, D. (2011). Pohybová aktivita pro podporu zdraví dětí a mládeže [Physical activity for the promotion of health of children and youth]. Olomouc: Univerzita Palackého.

Trost, S. G., Pate, R. P., Sallis, J. F., Freedson, P. S., Tailor, W. C., Dowda, M., \& Sirard, J. (2002). Age and gender differences in objectivily measured physical activity in youth: General comments and conlusions. Medicine and Science in Sports and Exercise, 34, 350-355.

Ulijaszek, S. J., Johnston, F. E., \& Preece, M. A. (1998). The Cambridge encyclopedia of human growth and development. Cambridge: University Press.

Vignerová, J., Bláha, P., Riedlová, J., Kobzová, J., Krejčovský, L., \& Brabec, M. (2005). Dlouhodobé změny růstu české dětské populace [Long-term changes in the growth of Czech children population]. Česko-slovenská pediatrie, 60, 274-280.

Weiner, J. S., \& Lourie, J. A. (1969). Human biology: A guide to field methods (IBP HANDBOOK No. 9). Oxford: Blackwell Scientific.

Wilmore, J. H., Costill, L. D., \& Kenney, L. W. (2008). Physiology of sport and excercise. Champaign, IL: Human Kinetics.

\section{POROVNÁNÍ SOMATICKÉHO STAVU A ÚROVNĚ MOTORICKÉ VÝKONNOSTI 7-15LETÝCH CHLAPCŮ Z OLOMOUCKÉHO A OPOLSKÉHO REGIONU}

(Souhrn anglického textu)

VÝCHODISKA: V posledních letech pozorujeme u dětí a mládeže pokles habituální pohybové aktivity a převládající způsob sedavého způsobu života. Odrazem těchto negativních trendů je i pokles motorické výkonnosti.

CÍLE: Cílem výzkumu je analyzovat úroveň motorických schopností současných 7 až 15letých olomouckých a opolských chlapců a somatické parametry olomouckých a opolských chlapců porovnat s 6 . CAV 2001.

METODIKA: Výzkum se uskutečnil v olomouckém a opolském regionu. Bylo změřeno a testováno 695 chlapců z olomouckého a 313 chlapců z opolského regionu ve věku 7 až 15 let. $\mathrm{K}$ diagnostice úrovně motorické výkonnosti chlapců byly použity standardizované motorické testy: skok daleký z místa odrazem snožmo, leh-sed s otáčením trupu za 1 min., člunkový běh $4 \times 10 \mathrm{~m}$ a hod těžkým míčem obouruč a testová baterie UNIFITTESTU (6-60). Ke statistickému hodnocení výsledků byl použit Studentův t-test pro jeden výběr, Z-skore, neparametrický $\chi^{2}$-test dobré shody.

VÝSLEDKY: Výsledky ukázaly, že v tělesné výšce a hmotnosti mají olomoučtí a opolští chlapci shodné parametry, které odpovídají i referenčním údajům 6. CAV 2001. Stejné výkonnostní úrovně dosahují oba soubory v testu člunkový běh $4 \times 10 \mathrm{~m}$ a skok daleký z místa odrazem snožmo. Nižšíi výkonnosti v porovnání s opolskými chlapci dosahuji olomoučtí chlapci v hodu těžkým míčem obouruč. V období mladšího školního věku dosahují olomoučtí chlapci lepší výkonnosti v testu leh-sed za 1 minutu. Hodnocení individuální motorické výkonnosti chlapců podle heterogenní testové baterie UNIFITTESTU (6-60) celkově ukázalo, že téměř 39 \% olomouckých a $42 \%$ opolských chlapců má podprůměrnou a výrazně podprůměrnou motorickou výkonnost. Komparace testových výsledků současných olomouckých a opolských chlapců s referenčními údaji olomouckých chlapců z let 2001 a 2002 naznačila pokles úrovně rychlostních schopností, vytrvalostně-silových schopností břišního svalstva a dynamicko-explozivních schopností horních a dolních končetin.

ZÁVĚRY: Pokles motorické výkonnosti olomouckých a opolských chlapců pravděpodobně odráží pokles habituální pohybové aktivity a převládající sedavý způsob života.

Klićová slova: chlapci 7 až 15 let, somatický stav, motorické schopnosti, motorické testy, mezinárodní srovnání. 